\title{
Streptococcus shiloi, the Name for an Agent Causing Septicemic Infection in Fish, Is a Junior Synonym of Streptococcus iniae
}

\author{
AVI ELDAR, ${ }^{1,2}$ PAUL F. FRELIER,${ }^{3}$ LILIANA ASSENTA, ${ }^{2}$ PATRICIA W. VARNER, ${ }^{3}$ \\ SARAH LAWHON, ${ }^{3}$ AND HERVE BERCOVIER ${ }^{1 *}$ \\ Department of Clinical Microbiology, The Hebrew University-Hadassah Medical School, Jerusalem 91010, ${ }^{1}$ and \\ Department of Poultry and Fish Diseases, The Kimron Veterinary Institute, Bet Dagan 50250, ${ }^{2}$ Israel, \\ and Department of Veterinary Pathology, Texas A\&M University, College Station, Texas 77843-4467 ${ }^{3}$
}

\begin{abstract}
Streptococcus shiloi strains, including the type strain, which were isolated in Israel and the United States, and Streptococcus iniae ATCC $29178^{\mathrm{T}}$ ( $\mathrm{T}=$ type strain) are phenotypically identical (as determined with API 20 STREP and API 50CH kits; beta-hemolytic on sheep blood agar). DNA-DNA hybridization experiments revealed levels of homology of 77 to $100 \%$. Thus, $S$. shiloi should be considered a junior synonym of $S$. iniae. This bacterium is a major fish pathogen that is distributed worldwide.
\end{abstract}

Streptococcus iniae was described in 1976 by Pier and Madin (7), who isolated this bacterium from skin lesions of a captive Amazon freshwater dolphin (Inia geoffrensis). In 1994, we described a new streptococcal species that was isolated from diseased rainbow trout (Onchorynchus mykiss) in Israel and was named Streptococcus shiloi (2). This name was validated in 1995 (4). S. shiloi differed from S. iniae in G+C content (37 $\mathrm{mol} \%$ [2]; the G+C content of $S$. iniae is $32.9 \mathrm{~mol} \%$ [7]), pathogenicity and host range. $S$. shiloi was shown to be the etiologic agent of an acute meningoencephalitis that affects trout (3), and it was also shown to be the causative agent of a similar disease in tilapia (Oreochromis aurea $\times$ Oreochromis nilotica hybrids) along with Streptococcus difficile (2). S. shiloi and $S$. difficile were shown to have broad geographical distributions and broad host ranges (2). S. shiloi was also isolated from diseased tilapia in Taiwan and the United States, and $S$. difficile was isolated in Japan from sea-cultured yellowtails (Seriola quinqueradiata) (2).

The purposes of this work were to elucidate the taxonomic position of $S$. shiloi and to compare $S$. shiloi Israeli field isolates collected over the last 5 years with isolates collected in the United States during the last 2 years.

A total of 15 American isolates were compared with 19 Israeli isolates, including the type strain of $S$. shiloi (strain ND 2-16 [= CIP 103769]), 1 strain isolated in Taiwan, and S. iniae ATCC $29178^{\mathrm{T}}$ ( $\mathrm{T}=$ type strain) (Table 1$)$. All of the strains were isolated from diseased fish. The type of hemolysis was determined on Columbia agar base (Difco) supplemented with $5 \%$ (vol/vol) defibrinated sheep blood; the type of hemolysis produced on this medium was then compared with the type of hemolysis produced on the same medium supplemented with human or bovine blood. Biochemical reactions were determined with API 20 STREP and API 50CH systems (API, La Balmes Les Grottes, France). Most of the instructions of the manufacturer were followed; the only exception was the temperature of incubation, which was adjusted to $30^{\circ} \mathrm{C}$. Results were read after $24 \mathrm{~h}$ of incubation. DNA was extracted by a previously described method (2). DNA-DNA hybridization experiments were performed by using the hy-

${ }^{*}$ Corresponding author. Mailing address: Department of Clinical Microbiology, The Hebrew University-Hadassah Medical School, POB 1172, Jerusalem 91010, Israel. Phone: 972-2-758256. Fax: 972-2784010 . droxyapatite method described by Johnson and Ault (5) and Brenner et al. (1), except that the volumes used were modified (2). After denaturation by boiling, reassociation was allowed to proceed for $18 \mathrm{~h}$ at $60^{\circ} \mathrm{C}$. Duplicate reactions were performed, and each run was performed twice. The levels of DNA relatedness (relative binding ratios) and the differences in melting points between the homologous reactions and the heterologous reactions for the labeled reference strains and other strains were calculated as described previously $(1,2)$. The rate of self-reassociation of the labeled DNA was routinely $2.5 \%$, and this value was subtracted from the absolute hybridization ratios.

All 36 strains studied (Table 1) produced complete betahemolysis on the sheep blood-supplemented medium, whereas partial hemolysis was observed when the medium was supplemented with human or bovine blood. The reactions of the Israeli and American isolates, including S. shiloi ND 2-16 and $S$. iniae ATCC $29178^{\mathrm{T}}$, were identical when we used the API 20 STREP kit. The Voges-Proskauer, hippurate, and $\alpha$ and $\beta$-galactosidase activity tests were negative, whereas the esculin hydrolysis and pyrrolidonylarylamidase, alkaline phosphatase, leucine arylamidase, and arginine dehydrolase activity tests were positive. Ribose, mannitol, trehalose, starch, and glycogen were acidified by all of the isolates, whereas none of the isolates acidified arabinose, sorbitol, lactose, inuline, or raffinose. S. iniae ATCC $29178^{\mathrm{T}}$ and six randomly selected Israeli and American strains were also tested by using API $50 \mathrm{CH}$ kits. Tests for acidification of ribose, galactose, D-glucose, D-fructose, D-mannose, mannitol, methyl-D-mannoside, $N$-acetylglucosamine, arbutin, esculin, salicin, cellobiose, maltose, sucrose, trehalose, melezitose, starch, glycogen, and $\beta$-gentobiose were positive for all of the isolates, including S. iniae ATCC $29178^{\mathrm{T}}$. Tests for acidification of D-arabinose, L-arabinose, galactose, methyl-D-glucoside, L-sorbose, D-xylose, L-xylose, methylxyloside, rhamnose, lactose, D-raffinose, D-fucose, L-fucose, glycerol, sorbitol, inositol, dulcitol, erythritol, adonitol, xylitol, D-arabitol, L-arabitol, amygdalin, inulin, lyxose, gluconate, 2-keto-gluconate, 5-keto-gluconate, turanose, and taganose were negative for all of the strains, including $S$. iniae ATCC $29178^{\mathrm{T}}$.

The DNAs of $S$. shiloi ND 2-16 ${ }^{\mathrm{T}}$ and $S$. iniae ATCC $29178^{\mathrm{T}}$ were labeled and hybridized with each other and with the DNAs of field strains (Table 1). The high levels of DNA-DNA homology (77 to $100 \%)$ and the low $\Delta T_{m(e)}$ values $\left(1.4^{\circ} \mathrm{C}\right.$ or less) for the various isolates collected in Israel and the United 
TABLE 1. Levels of DNA-DNA homology for S. iniae and S. shiloi strains ${ }^{a}$

\begin{tabular}{|c|c|c|c|c|c|}
\hline \multirow{2}{*}{ Strain } & \multicolumn{3}{|c|}{ Origin } & \multicolumn{2}{|c|}{ Relative binding ratio with ${ }^{b}$ : } \\
\hline & Date $(\mathrm{mo} / \mathrm{yr})$ & Host $^{c}$ & Location & S. shiloi ND $2-16^{\mathrm{T}}$ & S. iniae ATCC $29178^{\mathrm{T}}$ \\
\hline 4B10M321 & 9/93 & Tilapia brain & Texas & 96 & $90(1.2)^{d}$ \\
\hline 4B10M322 & 9/93 & Tilapia brain & Texas & 77 & $\mathrm{ND}^{e}$ \\
\hline 4B10M331 & $10 / 93$ & Tilapia brain & Texas & 89 & $79(1.4)$ \\
\hline 4B10M332 & $10 / 93$ & Tilapia brain & Texas & 100 & $93(0.9)$ \\
\hline 4B10M34 & $10 / 93$ & Tilapia brain & Texas & 97 & $93(1.2)$ \\
\hline 4B10M38 & $11 / 93$ & Tilapia brain & Texas & 92 & ND \\
\hline 4B10M411 & $12 / 93$ & Tilapia brain & Texas & 100 & ND \\
\hline 4B10M412 & $12 / 93$ & Tilapia brain & Texas & 93 & ND \\
\hline 4B10M43 & $1 / 94$ & Tilapia brain & Texas & 100 & ND \\
\hline 4B10M45 & $1 / 94$ & Tilapia brain & Texas & 100 & ND \\
\hline 4B10M45 & $1 / 94$ & Tilapia brain & Texas & 90 & ND \\
\hline 4B10M47 & $2 / 94$ & Tilapia brain & Texas & ND & ND \\
\hline 4B10M52 & $3 / 94$ & Tilapia brain & Texas & 91 & ND \\
\hline 4B10M60 & $4 / 94$ & Tilapia brain & Texas & 93 & ND \\
\hline Idaho 1 & 1994 & Tilapia kidney & Idaho & 91 & ND \\
\hline S. iniae ATCC $29178^{\mathrm{T}}$ & 1976 & Freshwater dolphin skin abscess & United States & $90(0.8)$ & $100(0.0)$ \\
\hline S. shiloi ND $2-16^{\mathrm{T}}$ & $8 / 89$ & Tilapia brain & Afikim, Israel & $100(0.0)$ & $95(0.5)$ \\
\hline ND 04 & $8 / 88$ & Trout kidney & Afikim, Israel & $90(0.7)$ & ND \\
\hline ND 24 & $5 / 89$ & Trout brain & Ein Hamifraz, Israel & $98(0.5)$ & ND \\
\hline ND 26 & $5 / 89$ & Tilapia brain & Afikim, Israel & 93 & ND \\
\hline $\mathrm{CH} 1$ & $6 / 86$ & Tilapia kidney & Taiwan & 89 & ND \\
\hline Dan 1 & $4 / 89$ & Trout brain & Dan, Israel & $95(0.9)$ & $78(1.0)$ \\
\hline Dan 2 & $4 / 89$ & Trout brain & Amir, Israel & $92(0.4)$ & ND \\
\hline Dan 3 & $12 / 91$ & Trout brain & Dan, Israel & 77 & ND \\
\hline $\operatorname{Dan} 4$ & $12 / 91$ & Trout kidney & Dan, Israel & 93 & $83(1.3)$ \\
\hline Dan 5 & $12 / 91$ & Trout kidney & Dan, Israel & 86 & ND \\
\hline Dan 6 & $12 / 91$ & Trout brain & Dan, Israel & 89 & ND \\
\hline Dan 7 & $12 / 91$ & Trout kidney & Dan, Israel & 93 & ND \\
\hline Dan 10 & $1 / 92$ & Coho salmon brain & Dan, Israel & 91 & ND \\
\hline Dan 12 & $2 / 92$ & Trout kidney & Dan, Israel & 90 & $93(1.1)$ \\
\hline Dan 14 & $2 / 92$ & Coho salmon brain & Dan, Israel & 95 & ND \\
\hline Dan 15 & 2/92 & Trout brain & Dan, Israel & 91 & ND \\
\hline Dan 16 & 2/92 & Trout brain & Dan, Israel & 92 & ND \\
\hline Dan 18 & $4 / 92$ & Trout brain & Dan, Israel & 83 & ND \\
\hline Dan 35 & $11 / 94$ & Trout brain & Dan, Israel & 78 & ND \\
\hline Dan 36 & $11 / 94$ & Trout brain & Dan, Israel & 81 & $90(1.1)$ \\
\hline
\end{tabular}

${ }^{a}$ Strains were isolated from diseased fish in Israel, the United States, and Taiwan.

${ }^{b}$ The relative binding ratios are the means of the values from four determinations, expressed as percentages of homologous binding.

'The scientific names of the fish are as follows: tilapia, Oreochromis aurea $\times$ Oreochromis nilotica hybrids; trout, Onchorynchus mykiss; Coho salmon, Onchorynchus kisutch; Amazon freshwater dolphin, Inia geoffrensis.

${ }^{d}$ The values in parentheses are $\Delta \mathrm{T}_{\mathrm{m}(\mathrm{c})}$ values (in degrees Celsius) $\left[\Delta T_{m(c)}\right.$ is the difference in melting points between the homologous reaction and the heterologous reaction]. These values reflect the levels of divergence in related DNA sequences and were not determined for all reactions.

e ND, not done.

States (Table 1) support the biochemical findings, indicating that all of the isolates which we tested are similar and belong to the same species. These organisms should be referred to as $S$. iniae and not $S$. shiloi. These two names are synonyms but because $S$. iniae (7) was published before $S$. shiloi $(2,4)$, only the name $S$. iniae should be retained. The differences in $\mathrm{G}+\mathrm{C}$ contents which have been observed may have been due to technical differences, and the data that we published previously (2) (which were determined by the high-performance liquid chromatography method) are probably more accurate than the data initially reported for $S$. iniae, which were determined by the denaturation method (7). Our conclusions have practical importance. S. iniae, which was described in 1976 on the basis of strains isolated in the United States (7), may have come to Israel in imported fish eggs in the early 1980s. The United States now imports tilapia from Israel. Disease due to $S$. iniae in tilapia in the United States may be caused by imported $S$. iniae strains or local $S$. iniae strain; only a molecular epidemiological study could answer this question. While only poorly defined group B streptococci were shown to infect fish in the
United States or Japan $(6,8)$, our data show that $S$. iniae not only is a pathogen of captive freshwater dolphins, but also is a major fish pathogen responsible for fish mortality in trout in Israel and in tilapia in the United States, Israel, and Taiwan.

We thank O. Bouvet for determining the $S$. shiloi $\mathrm{G}+\mathrm{C}$ content and Y. Bejerano, S. Nitzan, and A. Horowicz for providing strains in Israel. This work was funded by grant IS $2307-93$ from the US-Israeli BARD Foundation.

\section{REFERENCES}

1. Brenner, D. J., G. R. Fanning, A. V. Rake, and K. E. Johnson. 1969. Batch procedure for thermal elution of DNA from hydroxyapatite. Anal. Biochem. 28:447-459.

2. Eldar, A., Y. Bejerano, and H. Bercovier. 1994. Streptococcus shiloi and Streptococcus difficile: two new streptococcal species causing a meningo-encephalitis in fish. Curr. Microbiol. 28:139-143.

3. Eldar, A., Y. Bejerano, A. Livotf, A. Horovitcz, and H. Bercovier. 1995. Experimental streptococcal meningo-encephalitis in cultured fish. Vet. Microbiol. 43:33-40.

4. International Journal of Systematic Bacteriology. 1995. Validation of the publication of new names and new combinations previously effectively pub- 
lished outside the IJSB. List no. 52. Int. J. Syst. Bacteriol. 45:197-198.

5. Johnson, J. L., and D. A. Ault. 1978. Taxonomy of the Bacteroides. II. Correlation of phenotypic characteristics with DNA homology groupings for Bacteroides fragilis and other saccharolytic Bacteroides species. Int. J. Syst. Bacteriol. 28:257-265.

6. Kitao, T., T. Aoki, and R. Sakoh. 1981. Epizootic caused by $\beta$-haemolytic
Streptococcus species in cultured freshwater fish. Fish Pathol. 15:301-307.

7. Pier, G. B., and S. H. Madin. 1976. Streptococcus iniae sp. nov., a betahemolytic streptococcus isolated from an Amazon freshwater dolphin, Inia geoffrensis. Int. J. Syst. Bacteriol. 26:545-553.

8. Robinson, J. A., and F. P. Meyer. 1966. Streptococcal fish pathogen. J. Bacteriol. 92:512. 